\title{
Study of nitrate accumulation in herbs of Thymus pulegioides $L$. for flora of Ukraine
}

\author{
Ya. M. Steshenko iD*B,C,D, O. V. Mazulin iDA,D,E,F \\ Zaporizhzhia State Medical University, Ukraine
}

A - research concept and design; B - collection and/or assembly of data; C - data analysis and interpretation; D - writing the article; $\mathrm{E}$ - critical revision of the article; $\mathrm{F}$ - final approval of the article

Thymus pulegioides L. syn. (Thymus ovatus Mill.) of family, Lamiaceae is a fairly common species in Ukraine. Given the literature data, the studied species needs a more thorough study of nitrate accumulation due to the ecological situation in Ukraine, as well as the search for herbal medicinal products with sufficient raw material base and a minimum amount of carcinogenic and harmful substances.

The aim of the research: To determine the quantitative content of nitrates in the infusion of grass (1:10) Thymus pulegioides $L$. flora of Ukraine, using the ionometric method of analysis.

Materials and methods. Infusion of Thymus pulegioides L. (1:10) harvested in different regions of Ukraine was studied with the help of the ionometric method of analysis.

Results. The accumulation of nitrates was quantified for Thymus pulegioides $\mathrm{L}$. depending on the growing region, using the ionometric method of analysis. The data obtained during the study of the nitrates accumulation in the grass of the species varied from $62.55 \pm 7.31$ to $232.44 \pm 24.11$ which do not exceed the generally accepted sanitary norms. Summarizing the study, it was found that the minimum accumulation of nitrates in HRM was found in Poltava and Dnipropetrovsk regions (environment)

Conclusions. Given the data obtained, it can be concluded that the study of species of the genus Thymus L. by ionometric method of analysis for nitrate content to control the quality of plant raw materials and drugs based on it was relevant. The central part of Ukraine is a promising and ecologically safe region for the growth of the studied species.

Key words: Thymus pulegioides L., herb, ionometric method of analysis, nitrates.

Current issues in pharmacy and medicine: science and practice 2020; 13 (3), 337-340

Дослідження накопичення нітратів у траві Thymus pulegioides L. фрлори України

\section{Я. М. Стешенко, О. В. Мазулін}

Чебрець блошиний (Thymus pulegioides L. син. округлий (Thymus ovatus Mill.)) родини Ясноткові-вид, доволі поширений на території України. Враховуючи дані фрахової літератури, вид потребує ретельнішого дослідження накопичення нітратів у зв'язку з екологічною ситуацією в Україні та необхідністю пошуку фітопрепаратів із достатньою сировинною базою, мінімальною кількістю канцерогенних і шкідливих речовин .

Мета роботи - за допомогою іонометричного методу аналізу визначити кількісний вміст нітратів у настої трави (1:10) Thymus pulegioides L. флори України.

Матеріали та методи. Для експериментальних досліджень використовували настій із трави Thymus pulegioides L. (1:10), котру зібрали в різних регіонах України за допомогою іонометричного методу аналізу.

Результати. За допомогою іонометричного методу аналізу кількісно визначили накопичення нітратів залежно від регіону зростання Thymus pulegioides L. Дані накопичення нітратів у траві виду становили від $62,55 \pm 7,31$ до 232,44 $\pm 24,11$, що не перевищує санітарні норми. Встановили, що мінімальне накопичення нітратів у лікарській рослинній сировині виявили в Полтавській, Дніпропетровській областях (довкілля).

Висновки. Враховуючи дані, що одержали, можна зробити висновок: дослідження видів роду Thymus L. іонометричним методом аналізу на вміст нітратів для контролю якості рослинної сировини та лікарських засобів на її основі $є$ актуальним. Перспективний та екологічно безпечний регіон для зростання досліджуваного виду - центральна частина України.

Ключові слова: чебрець блошиний, трава, іонометричний метод аналізу, нітрати.

Актуальні питання фрармацевтичної і медичної науки та практики. 2020. Т. 13, № 3(34). С. 337-340

ARTICLE

INFO

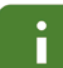

http:l/pharmed.

zsmu.edu.ualarticle/ view/216181
UDC 615.322:582.929.41.074:546.175]-047.37

DOI: $10.14739 / 2409-2932.2020 .3 .216181$

Current issues in pharmacy and medicine: science and practice 2020; 13 (3), 337-340

Key words: Thymus pulegioides L., herb, ionometric method of analysis, nitrates.

*E-mail: anastesenko07@gmail.com

Received: 21.09.2020 // Revised: 30.09.2020 // Accepted: 02.10.2020 


\section{Исследование накопления нитратов в траве Thymus pulegioides L. фрлоры Украины}

\section{Я. Н. Стешенко, А. В. Мазулин}

Тимьян блошиный (Thymus pulegioides L. син. округлый (Thymus ovatus Mill.)) семейства Яснотковые - вид, довольно распространенный на территории Украины. Учитывая данные научной литературы, этот вид требует более тщательного исследования накопления нитратов в связи с экологической ситуацией в Украине и необходимостью поиска фитопрепаратов с достаточной сырьевой базой и минимальным количеством канцерогенных и вредных веществ.

Цель работы - с помощью ионометрического метода анализа определить количественное содержание нитратов в настое травы (1:10) Thymus pulegioides L. фрлоры Украины.

Материалы и методы. Для экспериментальных исследований использовали настой травы Thymus pulegioides L. (1:10), которую собрали в различных регионах Украины с помощью ионометрического метода анализа.

Результаты. С помощью ионометрического метода анализа было количественно установлено накопление нитратов в зависимости от региона произрастания Thymus pulegioides L. Данные накопления нитратов в траве вида составили от $62,55 \pm 7,31$ до $232,44 \pm 24,11$, что не превышает санитарные нормы. Установлено, что минимальное накопление нитратов в лекарственном растительном сырье обнаружено в Полтавской, Днепропетровской областях (окружающая среда).

Выводы. Учитывая полученные данные, можно сделать вывод: исследование видов рода ионометрическим методом анализа на содержание нитратов для контроля качества растительного сырья и лекарственных средств на ее основе является актуальным. Перспективный и экологически безопасный регион для произрастания исследуемого вида - центральная часть Украины.

Ключевые слова: тимьян блошиный, трава, ионометрический метод, нитраты.

Актуальные вопросы фрармацевтической и медицинской науки и практики. 2020. Т. 13, № 3(34). С. 337-340

At present, the main problem in ecology is the state of the environment and the impact of anthropogenic harmful factors on environmental pollution. Every year the level of chemical pollution in Ukraine is exacerbated due to scientific and technological progress and careless attitude of people to the environment. It is known that the level of accumulation of harmful substances depends on many factors: the type, location of the plant, soil moisture, and the use of mineral fertilizers. It should be noted that the high level of environmental pollution leads not only to the accumulation of nitrates but also significantly increases the number of pesticides in different parts of plants. It is known in the scientific literature that nitrates have a negative effect on the cardiovascular and excretory systems. Information on the permissible content of nitrates in herbal raw material (HRM) and extracts from it is insufficient, so it is an important aspect in modern pharmacy and phytotherapy to review the accumulation of nitrates in little-studied species of medicinal plants. Existing quality control methods (QCM) only determine the presence and content of active substances, total ash, and other indicators [1,2,6].

The content of nitrates in plants depends on their biological properties, environmental conditions, and plant variety. The family Lamiaceae is one of the most numerous and widespread in the modern world flora. It has up to 200 genera and 7.000 species of grasses, shrubs, and semi-shrubs. Most of them have medicinal properties and are widely used in herbal medicine and cosmetology. Species of the genus Thymus $\mathrm{L}$. (Thyme), one of the most famous in this family, number about 400 members, of which up to 50 have been identified in the modern flora of Ukraine.

Promising for research and harvesting is a wild species of broad-leaved (Thymus pulegioides L.) syn. (Thymus ovatus Mill.) is widespread in central Europe. In Ukraine, it grows mainly in the southern and central parts of the country. The vegetation period of the plant is long (June-October), so the maximum period of accumulation of biologically active compounds depends on climatic conditions and the territorial location of plants (humidity, soil characteristics, duration of sunshine).

Therefore, the evaluation of the possible accumulation of nitrates during the growing season is of great practical importance for obtaining safe plant raw materials and the manufacture of phytopreparations based on it. Among the factors determining the degree of nitrates accumulation, the main roles are played by climatic, geomorphological and anatomical ones, as well as morphological features of the plant species. A comprehensive study of any plant group can only be done through a complete floristic analysis. Raw materials were harvested in herbaceous forest-steppe phytocenoses of Ukraine [1-9].

\section{Aim}

To determine the quantitative content of nitrates in the infusion of grass (1:10) Thymus pulegioides L. flora of Ukraine, using the ionometric method of analysis.

\section{Materials and methods of research}

For the experimental studies, we used the herb plant material Thymus pulegioides L. which was harvested in different regions of Ukraine during the flowering phase (June-October 2017-2018) in accordance with commonly accepted requirements. During experimental studies, the accumulation of nitrates in plant medicinal raw materials was documented.

The qualitative composition of nitrate compounds was determined by pharmacopoeial reaction with diphenylamine in concentrated sulphatic acid [4]. The quantitative content of 
Table 1. The results of the quantitative determination of the number of nitrates in herbs and infusions of herbs (1:10) of the genus Thymus $L$. (June-October 2017-2018), $(x \pm \Delta x), \% \mu=6$

\begin{tabular}{|l|l|l|l|}
\hline Plant species & Harvest location & Content in HRM, $\mathrm{mg} / \mathrm{kg}$ & Content in infusions (1:10), $\mathrm{mg} / \mathrm{l}$ \\
\hline \multirow{5}{*}{ Thymus pulegioides L. } & Zaporizhzhia region, Zaporizhzhia & $232.44 \pm 24.11$ & $112.61 \pm 12.36$ \\
\cline { 2 - 4 } & Poltava region, Hlobyne & $126.76 \pm 13.55$ & $64.34 \pm 7.22$ \\
\cline { 2 - 4 } & Kherson region, Henichesk & $218.23 \pm 19.64$ & $129.77 \pm 13.94$ \\
\cline { 2 - 4 } & Mykolaiv region, Olexandria & $224.35 \pm 21.82$ & $118.18 \pm 12.79$ \\
\cline { 2 - 4 } & Zaporizhzhia region, Volodymyrivka village & $167.28 \pm 17.39$ & $85.45 \pm 9.12$ \\
\hline & Dnipropetrovsk region, Apostolove & $115.75 \pm 12.72$ & $62.55 \pm 7.31$ \\
\hline
\end{tabular}

nitrates was determined by ionometric method on the device EV-74 (Republic of Belarus, JSC “Gomel Plant of Measuring Instruments") with nitrate-selective electrode type EI-NO3 ${ }^{-}$ (reference electrode - silver chloride EVL-1 MZ). In the phytochemical laboratory of the department, a standard solution of potassium nitrate $(\mathrm{CP})$ with a concentration of $0.1 \mathrm{~mol} / 1$ was used to prepare working solutions with concentrations of $\mathrm{C} 1=0.01 \mathrm{~mol} / 1, \mathrm{C} 2=0.0001 \mathrm{~mol} / 1$ in $1 \%$ solution of potassium alum.

The weighted amount of the test sample of $10 \mathrm{~g}$ (exact amount) was ground to a powdery state and transferred to a $100 \mathrm{ml}$ volumetric flask. Then $50 \mathrm{ml}$ of $1 \%$ solution of potassium alum was added, carefully stirred for $3 \mathrm{~min}$, the electrode potential $(\mathrm{mV})$ was measured, and with the help of a calibration graph the nitrate content was calculated. For the analysis of infusions (1:10) with the herbal raw material (HRM) $10 \mathrm{ml}$ of the pharmaceutical form was used. Due to the absence of standardizing documentation regulating the presence of these substances, we used the maximum permissible concentration (MPC) regulations for agricultural plant products (up to $350 \mathrm{mg} / \mathrm{kg}$ ) to determine safety. For the study of infusions $(1: 10)$ from raw materials, we used $10 \mathrm{ml}$ of the medicinal form.

\section{Results}

The research results are given in Table 1. According to the pharmaceutical regulatory documents on analytical method validation, which have clearly established sanitary norms that regulate the content of nitrates in drinking water for human consumption, where the maximum permissible concentrations (MPC) should not exceed $10 \mathrm{mg} / \mathrm{l}$; in herbaceous agricultural plants $300-370 \mathrm{mg} / \mathrm{kg}$; rhizomes and roots $400-450 \mathrm{mg} / \mathrm{kg}$ [10-12]. During the study, it was found that the accumulation of nitrates in the grass Thymus $L$. ranges from $62.55 \pm 7.31$ to $232.44 \pm 24$.11. The content of nitrates did not exceed the existing sanitary norms of the MPC.

\section{Discussion}

The obtained data support the perspective of using the ionometric method of analysis to control the quality of potential medicinal raw materials.

\section{Conclusions}

1. With the help of experimental studies of the HRM the level of nitrate accumulation was estimated as ranging from $62.55 \pm 7.31$ to $232.44 \pm 24.11$.

2 . The presence and content of nitrates indicate that the accumulation of substances depends on the conditions of growth of the species and the territorial location of Thymus pulegioides $\mathrm{L}$.

3. Deterioration of the ecological condition of the environment is the main problem for finding safe plant raw materials that would accumulate a minimum amount of harmful substances during the growing season.

4. Summarizing the study, it was found that the minimum accumulation of nitrates in HRM was found in Poltava and Dnipropetrovsk regions (environment).

Prospects for further research. The data obtained by the experimental study can be used for further phytochemical and ecological studies of Thymus pulegioides L. syn. (Thymus ovatus Mill.), as well as for the standardization of HRM of the studied species of the genus Thymus L. for nitrate content. The central part of Ukraine is a promising and ecologically safe region for the growth of the studied species.

Conflicts of interest: authors have no conflict of interest to declare. Конфлікт інтересів: відсутній.

Information about authors:

Steshenko Ya. M., Postgraduate student of the Department of Clinical

Pharmacy, Pharmacotherapy, Pharmacognosy and Pharmaceutical

Chemistry, Zaporizhzhia State Medical University, Ukraine.

ORCID ID: 0000-0002-7538-6740

Mazulin O. V., Dr.hab., Professor of the Department of Clinical Pharmacy,

Pharmacotherapy, Pharmacognosy and Pharmaceutical Chemistry,

Zaporizhzhia State Medical University, Ukraine.

ORCID ID: 0000-0003-0628-4457

Відомості про авторів:

Стешенко Я. M., PhD-аспірант каф. клінічної фармації, фармакотерапії, фрармакогнозії та фармацевтичної хімії, Запорізький державний медичний університет, Україна.

Мазулін О. В., д-р фарм. наук, професор каф. клінічної фармації, фармакотерапії, фрармакогнозії та фрармацевтичної хімії, Запорізький державний медичний університет, Україна.

Сведения об авторах:

Стешенко Я. H., PhD-аспирант каф. клинической фармации, фрармакотерапии фармакогнозии и фрармацевтической химии, Запорожский государственный медицинский университет, Украина. 
Мазулин А. В., д-р фарм. наук, профессор каф. клинической фармации, фармакотерапии, фармакогнозии и фрармацевтической химии, Запорожский государственный медицинский университет, Украина.

\section{References}

[1] Tzima, K., Brunton, N. P., \& Rai, D. K. (2018). Qualitative and Quantitative Analysis of Polyphenols in Lamiaceae Plants-A Review. Plants, 7(2), 25. https://doi.org/10.3390/plants7020025

[2] Pavel, M., Ristić, M., \& Stević, T. (2010). Essential oils of Thymus pulegioides and Thymus glabrescens from Romania: chemical composition and antimicrobial activity. Journal of The Serbian Chemical Society, 75, 27-34. https://doi.org/10.2298/JSC1001027P

[3] Kabata-Pendias, A. (2010). Trace elements in soils and plants, fourth edition (4th ed.). Boca Raton, FL: CRC Press. https://doi.org/10.1017/ $\underline{\text { S0014479711000743 }}$

[4] Bubenchikova, V. M., Popova, N. V., \& Starchak, Yu. A. (2014). Caffeic and rosmarinic acids in Thyme Species. News of pharmacy, (4), 13-16. https://doi.org/10.24959/nphj.14.1986

[5] Nabavi, S. M., Marchese, A., Izadi, M., Curti, V., Daglia, M., \& Nabavi, S. F. (2015). Plants belonging to the genus Thymus as antibacterial agents: from farm to pharmacy. Food chemistry, 173, 339-347. https:// doi.org/10.1016/j.foodchem.2014.10.042

[6] Kwee, E. M., \& Niemeyer, E. D. (2011).Variations in phenolic composition and antioxidant properties among 15 basil (Ocimum basili- cum L.) cultivars. Food Chemistry, 128(4), 1044-1050. https://doi. org/10.1016/j.foodchem.2011.04.011

[7] Salvaneschi, S., Iriti, M., Vitalini, S., \& Vallone, L. (2020). Thymus vulgaris $L$. as a possible effective substitute for nitrates in meat products. Italian journal of food safety, 9(2), 7739. https://doi.org/10.4081/ iifs.2020.7739

[8] López-Alarcón, C., \& Denicola, A. (2013). Evaluating the antioxidant capacity of natural products: a review on chemical and cellular-based assays. Analytica chimica acta, 763, 1-10. https://doi.org/10.1016/ j.aca.2012.11.051

[9] Vaičiulytè, V., Butkiene, R., \& Ložienè, K. (2016). Effects of meteorological conditions and plant growth stage on the accumulation of carvacrol and its precursors in Thymus pulegioides. Phytochemistry, 128, 20-26. https://doi.org/10.1016/j.phytochem.2016.03.018

[10] Akram, M., \& Rashid, A. (2017). Anti-coagulant activity of plants: mini review. Journal of Thrombosis and Thrombolysis, 44, 406-411. https:// doi.org/10.1007/s11239-017-1546-5

[11] Soosaraei, M., Fakhar, M., Hosseini Teshnizi, S., Ziaei Hezarjaribi, H., \& Banimostafavi, E. S. (2017). Medicinal plants with promising antileishmanial activity in Iran: a systematic review and meta-analysis. Annals of Medicine and Surgery, 21, 63-80. https://doi.org/10.1016/ j.amsu.2017.07.057

[12] Burns, I. G., Durnford, J., Lynn, J., McClement, S., Hand, P., \& Pink, D. (2012). The influence of genetic variation and nitrogen source on nitrate accumulation and iso-osmotic regulation by lettuce. Plant and Soil, 352(1-2), 321-339. https://doi.org/10.1007/s11104-011-0999-0 